\title{
ZAŠTITNA ARHEOLOŠKA ISTRAŽIVANJA PROVEDENA NA LOKACIJI PRERADOVIĆEVA 14 U VARAŽDINU - PRILOG POZNAVANJU GRADSKIH GRABIŠTA
}

Zaštitna arheološka istraživanja provedena su tijekom 2007. godine na lokaciji Preradovićeva 14 u Varaždinu, za potrebe dogradnje I. gimnazije. Obuhvatila su dio zatrpanog istočnog grabišta, koje je bilo dio obrambenog sustava grada Varaždina od sredine 15. do početka 19. stoljeća. Provedena arheološka istraživanja uglavnom su nam potvrdila dostupne povijesne podatke o gradskom grabištu i njegovom zatrpavanju početkom 19. stoljeća, kao i rezultate ranije provedenih istraživanja na sličnim lokacijama u gradu Varaždinu. Od svih utvrđenih stratigrafskih jedinica najzanimljivija je ona koja predstavlja samo grabište, a u kojem je pronađena velika količina pokretnih arheoloških nalaza, koje možemo datirati u period od 15. do 19. stoljeća, što je ujedno i vrijeme funkcioniranja grabišta kao dijela obrambenog sustava grada Varaždina.

\section{UVODNE NAPOMENE}

Dogradnja I. gimnazije u Varaždinu bila je planirana na lokaciji Preradovićeva 14 i to na dijelu zatrpanog istočnog gradskog grabišta uz nekadašnje gradske 
bedeme. Grabište je bilo dio obrambenog sustava grada, te je u tom kontekstu bilo ispunjeno vodom. Planirana dogradnja nalazila se na dijelu grabišta koje je bilo uz ulicu Via Fossata ambiens, koja je okruživala čitav grad, a ne uz sam bedem. Ovakve lokacije arheološki su zanimljive zbog boljeg razumijevanja gradskog obrambenog sustava, ali i zbog pokretnih nalaza koji nam ocrtavaju sliku i razvoj grada.

Zbog arheološki zanimljivog prostora propisana sa arheološka istraživanja prije početka izgradnje. ${ }^{1}$ Radovi su započeli 28 . kolovoza 2007 . godine, a trajali su s prekidima, do 06. listopada 2007. godine. Zaštitna istraživanja, kojima se trebao utvrditi karakter lokaliteta, trajala su 10 radnih dana, a nakon toga na čitavom preostalom dijelu planirane građevine provedena su zaštitna istraživanja i arheološki nadzor u trajanju od još 10 radnih dana. Sredstva za predmetna istraživanja osigurao je investitor, tvrtka T.P.N. Varaždin, temeljem ugovora Klasa:612-08/07-03/10049, Urbroj: 532-04/4-07-1 od 27. kolovoza 2007. godine i ugovora Klasa:612-08/07-03/10049, Urbroj: 532-04/4-07-2 od 27. rujna 2007. godine, sklopljenih sa Ministarstvom kulture. Investitor je također osigurao stroj za iskop recentnog nasipa terena i fizičke radnike, kao i geodetsko snimanje, koje je provela je tvrtka Gim d.o.o. iz Varaždina.

Prvo su otvorene dvije sonde kojima je utvrđen karakter lokaliteta. Ukupno je otvoreno 6 sondi u kojima je izdvojeno 13 stratigrafskih jedinica, od kojih je najzanimljivija SJ 7, koja predstavlja samo grabište. Tu je pronađena veća količina pokretnih arheoloških nalaza, koje okvirno možemo datirati od 15. do 19. stoljeća. Najbrojniji nalazi su ulomci keramičkih posuda, od kojih najveći broj pripada posudama za svakodnevnu uporabu, ali je pronađeno i mnogo fragmenata koji su zeleno ocakljeni. Nešto je manja učestalost fragmenata pećnjaka i stakla, a najmanje ima metalnih nalaza. Ovo provedeno arheološko istraživanje upotpunilo nam je sliku razvoja grada Varaždina koju nam donose povijesni podatci, ali i ranije provedena arheološka istraživanja unutar zaštićene gradske jezgre.

\section{KRATKI PREGLED RAZVOJA GRADSKIH BEDEMA I GRABIŠTA}

Grad Varaždin zbog razvoja trgovine, obrta i novčane privrede općenito, doživljava svoj najveći procvat tijekom 15. stoljeća. To se sagledava kroz njegovu ubrzanu izgradnju i promjenu unutarnje strukture, ali i kroz činjenicu da to više nije neutvrđeni suburbij okupljen oko uličnog trga, već dobro organizirani grad s

1 Arheološka istraživanja provelo je Ministarstvo kulture, Uprava za zaštitu kulturne baštine, Konzervatorski odjel u Varaždinu, a za njihovog voditelja određena je Marijana Korunek, dipl. arheolog. 
uređenim utvrdama, ulicama i središnjim trgom. ${ }^{2}$ Gradski bedemi nastaju nakon 1446. godine, jer se tada još izrijekom navodi da je Varaždin neutvrđeni grad, koji je u osvajanju Janka Hunjadija uništen, ali tom prilikom sama utvrda nije bila osvojena. Sve to navelo je varaždinske građane da nekako osiguraju svoj grad, te se ubrzo počinju spominjati varoška utvrđenja u gradskim zapisnicima. ${ }^{3}$ Iz 1458. godine imamo podatak o palisadama na bedemu uz grabište.

Zapisnici dalje spominju gradska vrata i vratare, te gradski toranj u kojem se nalazio zatvor. Za ovaj toranj nije potvrđeno gdje se točno nalazio, ali pretpostavka je da je upravo on prikazan na grbu grada Varaždina, koji je 1464. godine Varaždincima dao Matija Korvin. Dakle, Varaždin je između 1446. i 1454. godine bio opasan zemljanim nasipima, učvršćen kolcima i živicom, te opkoljen vodom. ${ }^{4}$

Zbog osmanlijske opasnosti 1516. godine Ludovik II. ukida gradu sva davanja kako bi mogao izgraditi nove bedeme. Međutim, ta izgradnja zasigurno je već i ranije započela, ali nemamo očuvanih nikakvih podataka o tijeku gradnje. S postojećih tlocrta i nacrta možemo danas razabrati ugaone bastione i prostrane kule, povezane kurtinama, dok se uz zidove protezao zemljani nasip, a grabišta su se napunila vodom iz obližnje Drave. ${ }^{5}$

$U$ vrijeme renesanse, bedemi dobivaju oblik nepravilnog četverokuta s najsnažnijim dijelom na sjeverozapadu (današnji Stari grad). S vanjske strane, grabište je uz bedeme omeđivala Via Fossata ambiens. Tijekom vremena, zidovi i kule varoških bedema su popravljani, pa tako imamo podatak da se to zbilo 1573 . godine kada je očišćeno i grabište. Nakon toga 1582. godine Varaždin je zahvatio požar u kojem su stradali i bedemi. Francesco Marmoro obnavlja zidine ranije zahvaćene požarom. Martin Stier 1661. godine izrađuje nacrte postojećih bedema, ali i nacrte za novi obrambeni sustav. Međutim, ovaj projekat nikada nije izveden, jer se na svim kasnijim nacrtima vidi da je zadržan prijašnji oblik bedema. ${ }^{6}$

Slabljenjem osmanlijske opasnosti gubi se značaj i svrha obrambenog sustava, te se bedemi prestaju održavati, pa dolazi do njihovog propadanja. Istovremeno se započinje sa izgradnjom predgrađa, koja se razvijaju oko ulice

\footnotetext{
Mirela SLUKAN ALTIĆ, Povijesni atlas gradova - Varaždin, V. svezak, Zagreb 2009., 57.

Cijeli magistrat jednodušno 1454. godine odlučuje da se ima kazniti globom i zatvorom svako onaj, koji oštećuje gradske utvrde i grabišta; Mira ILIJANIĆ: „Varaždinske gradske zidine, Prilog historijatu našeg grada," Zbornik radova Urbanizam, graditeljstvo, kultura, Varaždin 1999., 157.

4 M. ILIJANIĆ, n. dj., 157.-159.

6 Isto, 158-159.
}

5 Isto, 158. 
Via Fossata ambiens. ${ }^{7}$ Početkom 19. stoljeća bedemi se spominju kao rasadišta bolesti i smrada, te se sukladno tome ukazala potreba za njihovim uklanjanjem. Dodatni razlog bio je i taj što se Varaždin do tada već razvio i izvan zidina, te su bedemi bili zapreka nesmetanoj komunikaciji, pa se zbog toga javljaju i prvi proboji zida. Baš je to otvaranje novih komunikacija bilo razlog promjenama grabišta, koje je do tada bilo jedinstveno oko čitavog grada. Naime, nove komunikacije nisu povezane mostovima, nego suhim prijelazima preko jarka. ${ }^{8}$ Tako je grabište podijeljeno u pet dijelova, što nam pokazuje slika 1.

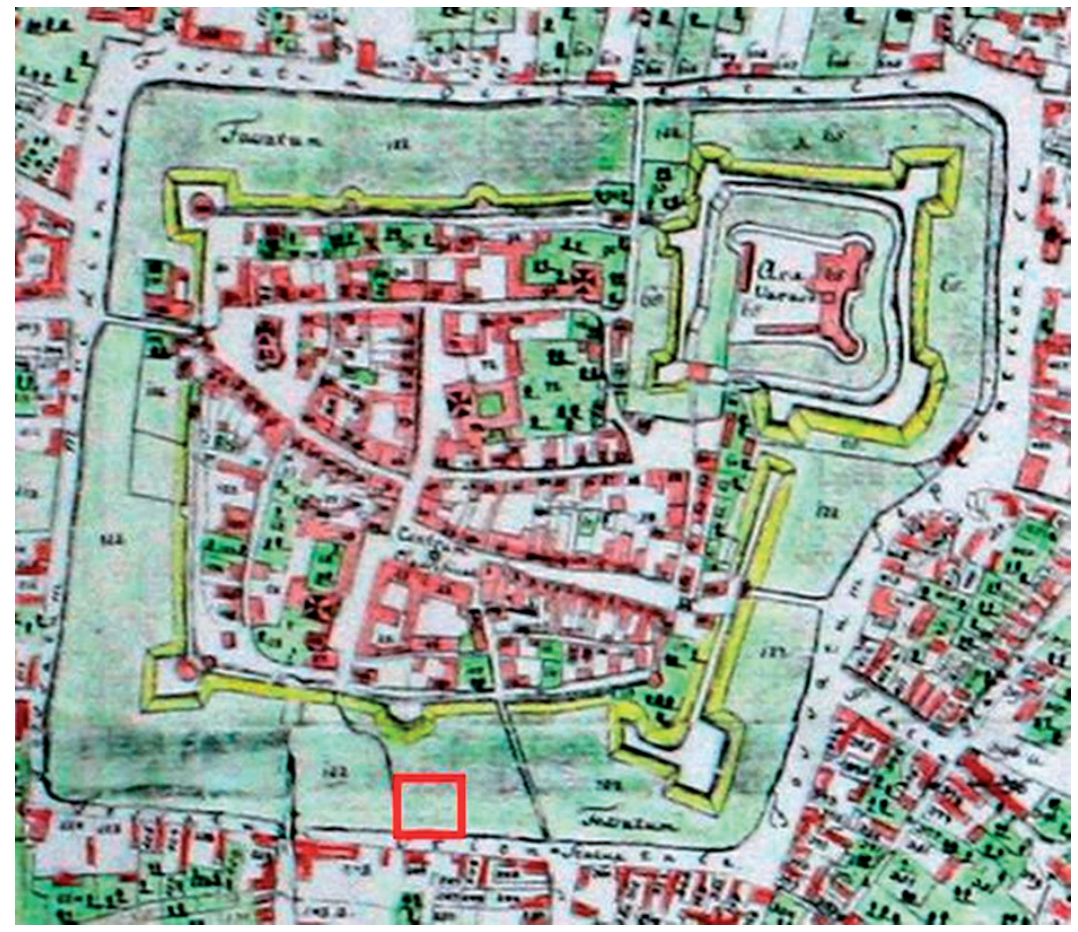

Slika 1. Ignacije Beyschlag, Tlocrt grada Varaždina iz 1807. godine, crvenom bojom označena pozicija dogradnje I. gimnazije u Varaždinu (dokumentacija KOVŽ)

Ivy LENTIĆ KUGLI, Varaždin nakon požara 1776, Zagreb 1973, 28.

8 Marija MIRKOVIĆ, „O spajanju unutarnje varoši i gradskih predgrađa,“ Godišnjak GMV, 1962./63.,4648. 


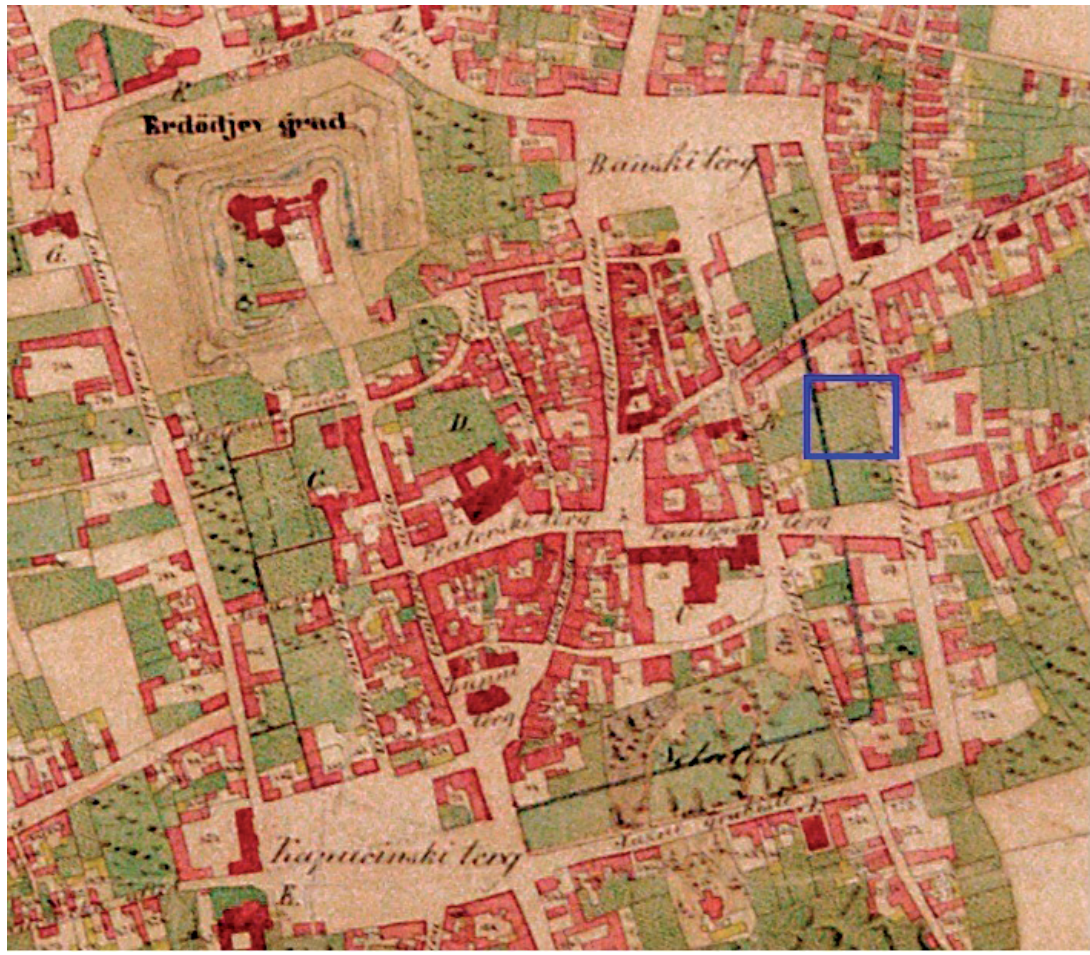

Slika 2. A. Kisweter, Plan grada Varaždina iz 1860. godine, plavom bojom označena pozicija dogradnje I. gimnazije u Varaždinu (dokumentacija KOVŽ)

Ovako započeto uništavanje gradskog obrambenog sustava nije se zaustavilo, nego je dovelo do odluke o sistematskom niveliranju grabišta 1806. godine. Plan za rušenje bedema i uređenje novonastalog prostora izrađuju županijski inžinjer Ignacije Beyschlag i inženjer Josip Erdödy, te zidarski majstori Urban Greiner i Grgur Lopich. Na početku predračuna nalazi se podatak da nije isplativo vaditi temelje gradskih bedema prilikom rušenja, a da je to tako i izvedeno potvrdila su nam arheološka istraživanja na dijelovima nekadašnjeg bedema. Ovim predračunom predviđeno je i da se voda iz grabišta svede u kanal koji bi proticao sredinom grabišta, a izgradio bi se od materijala iz gradskog bedema. Na nekim dijelovima to je izvedeno već 1810 . godine. ${ }^{9}$ Iz dostupnih povijesnih podataka doznajemo da su predradnje za rušenje bedema i zatrpavanje grabišta bile opse-

9 Johann Caesar, gradski inženjer spominje ga u svojim izvještajima o podjeli zemljišta na gruntovne čestice 1810. godine. Podatak preuzet iz članka M. MIRKOVIĆ, n. dj., 49. 
žan posao, koji je uključivao rušenje bedema do uličnog nivoa, zatrpavanje grabišta zemljom iz bedema, gradnju kanala za regulaciju vode, izgradnju mostova preko kanala, izradu urbanističke sheme novonastalog prostora za novu izgradnju. Nakon dobivenog odobrenja krenulo se s radovima koji su prvo započeli na zapadnom grabištu, koje je nivelirano i osposobljeno za gradnju. Isto je postupno izvedeno i na ostatku grabišta. Gradnja nije svugdje započela istovremeno zbog velike vlage u tek isušenim jarcima. ${ }^{10}$

Na planu grada Varaždina iz 1860. godine (slika 2) vidimo da na parceli na kojoj kasnije nastaje I. gimnazija i parceli na kojoj su provedena ova arheološka istraživanja nema nikakve čvršće izgradnje, nego su one označene kao zelena površina.

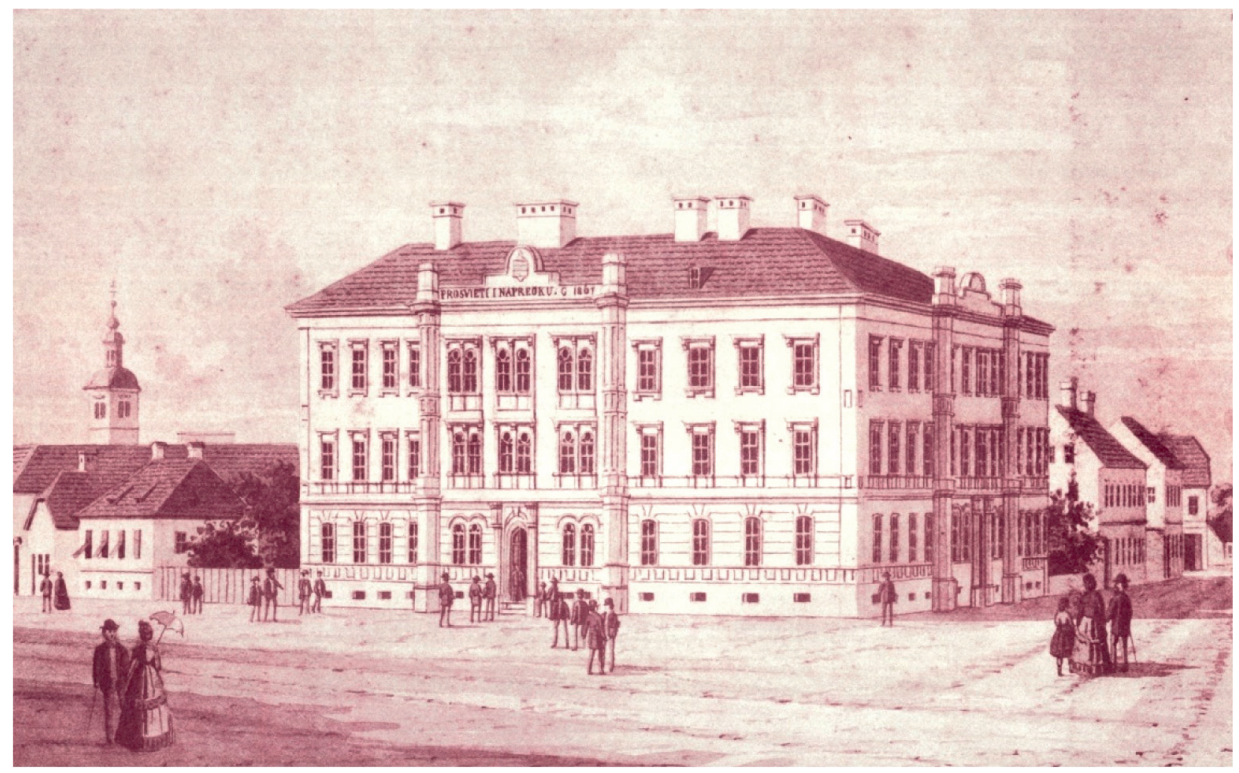

Slika 3. Veduta s prikazom I. gimnazije, 2. pol. 19. st. (dokumentacija KOVŽ)

U drugoj polovini 19. stoljeća nastaju reprezentativne građevine na parcelama zatrpanog gradskog grabišta. One su smještene na istaknutim uglovima, a trebale su zatvoriti blokove i oblikovati prilaze unutarnjem dijelu grada. To su zgrade kazališta, pošte i I. gimnazije. Zgrada I. gimnazije nastaje u periodu između 1867. i 1870. godine na uglu Pavlinske i Preradovićeve ulice. To je dvokatni

10 Detaljnije u: M. MIRKOVIĆ, n. dj., 42-66. 
samostojeći objekt smješten na sjevernoj strani ulice, koji je glavnim pročeljem okrenut prema jugu, a gradi ga Wilim Weiner u mješovitom stilu neoromanike i neogotike. ${ }^{11}$

Na veduti koja nastaje 80-tih godina 19. stoljeća djelomično se vidi i parcela sjeverno uz gimnaziju, na kojoj je sada planirana dogradnja I. gimnazije (slika 3). Jasno se prepoznaje istočni ogradni zid parcele, ali on je visok samo oko 1 metar. Nekoliko godina prije početka dogradnje I. gimnazije srušen je recentniji zid od opeke koji je nastao na tom mjestu, ali on je bio viši i imao je otvor na Preradovićevu ulicu. Na veduti se unutar parcele vidi drveće koje je dosta niže u odnosu na uličnu kotu.

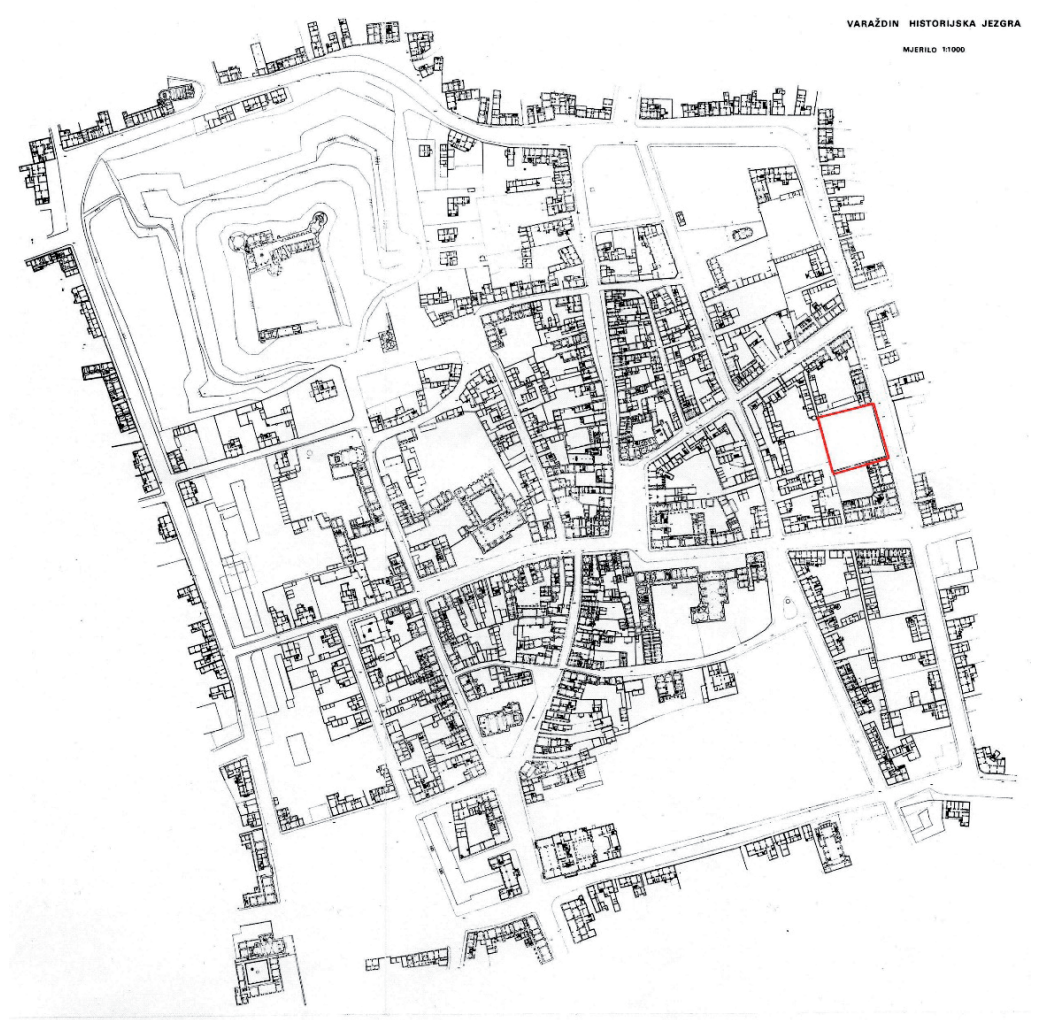

Slika 4. Snimak postojećeg stanja jezgre Varaždina 1969. godine, crvenom bojom označena je pozicija dogradnje I. gimnazije (dokumentacija KOVŽ)

11 Ivy LENTIĆ KUGLI, Zgrade varaždinske povijesne jezgre, Zagreb 2001., 120. 
Prema dostupnim povijesnim podacima, na parceli na kojoj je bila planirana dogradnja I. gimnazije u Varaždinu, nikada nije bilo čvršće arhitektonske izgradnje (slika 4). Nivo prije arheoloških istraživanja odgovara nivou ulice, ali je ovim istraživanjima utvrđeno da je nivo parcele bio znatno niži, što odgovara situaciji na južnom grabištu. Tamo nivo grabišta nije bio kod zatrpavanja izravnan s uličnom linijom, nego je ostalo udubljenje s nepravilnim nivoima, koje je kasnije iskorišteno kod planiranja parkovne cjeline.

\section{REZULTATI ARHEOLOŠKIH ISTRAŽIVANJA ${ }^{12}$}

Arheološka istraživanja na prostoru predviđene dogradnje I. gimnazije u Varaždinu započela su 28. kolovoza 2007. godine. Glavna građevina bila je planirana u duljini od 40,18 m i širini od 19,65 m, sa dogradnjom na zapadnoj strani, koja je bila dugačka 19,24 m, a široka

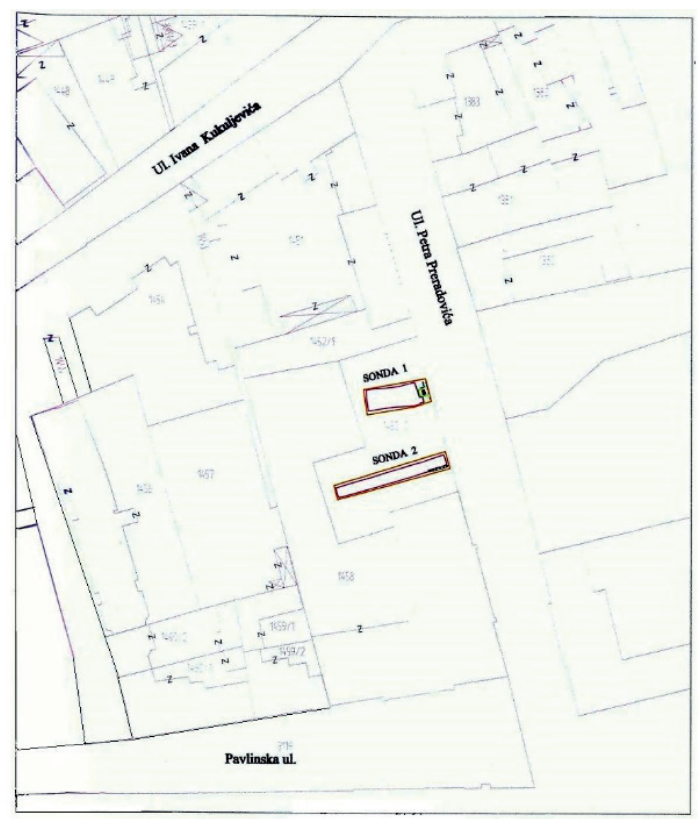
13,80 m. Preliminarnim pregledom terena prije početka radova utvrđeno je da se na istočnoj i južnoj strani čitavom širinom i dužinom parcele protežu kameni zidovi, čija je gornja zona bila vidljiva u razini zatečenog terena. Obzirom da su na početku bila planirana preliminarna arheološka istraživanja kojima bi se utvrdilo stvarno stanje terena i arheoloških struktura, prvo su otvorene dvije sonde, sonda $1 \mathrm{i}$ sonda 2 (slika 5), te se temeljem dobivenih rezultata odredilo daljnje postupanje.

Slika 5. Položaj sonde 1 i sonde 2

(Gim d.o.o. iz Varaždina)

12 Rezultati provedenih arheoloških istraživanja obrađeni su u Marijana KORUNEK, Varaždin, Preradovićeva 14 - Rezultati zaštitnih arheoloških istraživanja i arheološkog nadzora, izvješće iz prosinca 2007. (dokumentacija KOVŽ) i djelomično objavljeni u: Marijana KORUNEK, „Varaždin - Preradovićeva 14, arheološka iskopavanja," Hrvatski arheološki godišnjak 4/ 2007, Zagreb 2008., 167 - 169. 


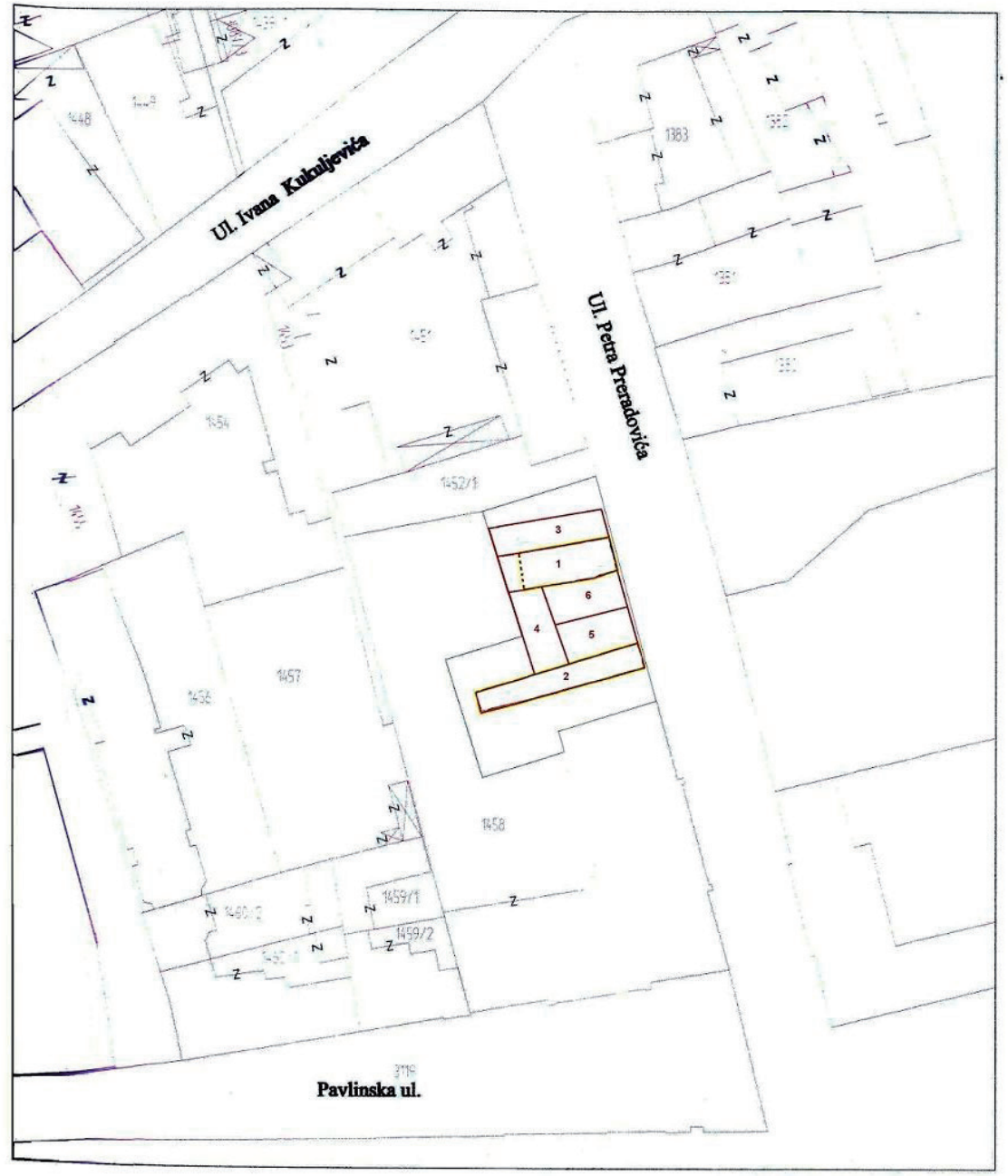

Slika 6. Raspored svih istraženih sondi (Gim d.o.o. iz Varaždina)

Tijekom svih provedenih istraživanja otvoreno je ukupno 6 sondi (slika 6) u kojima je izdvojeno 13 stratigrafskih jedinica i to:

SJ 1 - recentni nasip - ova SJ bila je sačinjena od sitnog šljunka pomiješanog sa opekom, kamenjem i građevinskom šutom, te betonskim elementima. Ovo je recentni nasip terena iz 70-tih godina 20. stoljeća (sonde 1, 2, 3, 4, $5,6)$.

SJ 2 - kameni bunar s betonskom kapom i poklopcima - bunar je građen od kamena i on je stariji. Kasnije dobiva betonsku kapu i dva betonska poklop- 
ca. Zatrpan je do dubine od cca 2,50 m, od visine kape. Smješten je neposredno uz istočni ogradni zid parcele (sonda 1 ).

SJ 3 - opločenje od opeke - pronađeno je uz bunar (SJ 2) i najvjerojatnije je u vrijeme funkcioniranja bilo povezano s njime. Smješteno je uz istočni ogradni zid parcele. Građeno je od dva reda opeka postavljenih jedan iznad drugoga (sonda 1).

SJ 4 - urušenje kamenog zida - pronađeno je južno uz opločenje od opeke (SJ 3), a očito se radi o urušenom istočnom ogradnom zidu parcele, koje se sastoji od kamena, veziva i mjestimično opeke (sonda 1,6).

SJ 5 - sloj humusa (vrtovi) - gornja razina ove SJ predstavlja razinu funkcioniranja terena do 70 -tih godina 20 . st.; na ovoj razini funkcioniranja pronađeni su SJ 2 i SJ 3; ovdje su bili vrtovi i voćnjak (sonda 1, 2, 3, 4, 5, 6).

SJ 6 - nasip grabišta - ova SJ je nasip terena koji možemo datirati u 19. stoljeće; u njemu su pronađeni pokretni nalazi keramike, te nekoliko ulomaka stakla i metalnih predmeta (sonda 1, 2, 3, 4, 5, 6).

SJ 7 - grabište - ova SJ čini osušeni mulj grabišta sive boje u kojem je pronađeno najviše pokretnih arheoloških nalaza (keramika, pećnjaci, staklo i metal); najniži dio je sloj batude označen kao SJ 7A, a između batude također se nailazilo na pokretne arheološke nalaze (sonda 1, 2, 3, 4, 5, 6).

SJ 8 - zid od opeke - zidan je od 6 redova opeke, od kojih su dva donja reda ispod hodne površine (SJ 5), te tako predstavljaju njegov temelj; zid je bio pravokutnog tlocrta (sonda 2).

SJ 9 - sloj od opeke - horizontalno pravilan sloj od opeka koje se lome; djelomično sadrži i kamen; determiniran je unutar SJ 5 (sonda 1,2).

SJ 10 - zdravica - žućkasti dravski pijesak (sonda 1, 2, 3, 4, 5, 6).

SJ 11 - vapnara - gašeno vapno (tlocrt- izduženi kružni oblik); nalazi se unutar SJ 6 i SJ 7 (sonda 1 A, 3).

SJ 12 - kameni zid (istočni) - ovo je istočni ogradni zid parcele koji je u cijelosti očuvan do razine današnje ulice; temelj mu započinje na gornjoj razni SJ 5 (sonda 1, 2, 3, 5, 6).

SJ 13 - kameni zid (južni) - u potpunosti je očuvan do današnje razine ulice, osim na dva mjesta gdje su vršena ispitivanja temelja postojeće zgrade I. gimnazije (sonda 2). 


\section{Sonda 1}

Ova sonda otvorena je približno u sredini planirane glavne građevine. Dimenzije sonde u početku su iznosile $6 \times 6 \mathrm{~m}$, ali je ona kasnije produžena prema zapadu za još $10 \mathrm{~m}$, te je tada geodetski snimljena. Tijekom druge faze istraživanja sonda je dodatno produžena za još 3 metra, te time ukupne dimenzije iznose $6 \times 19$ metara.

Sonda je otvorena od istočnog ogradnog zida parcele (SJ 12), prema zapadu. Prva pretpostavka bila je, da je ovaj zid temelj nedavno srušenog ogradnog zida od opeke. Međutim, već je prva sonda pokazala da je ovo stariji zid kojem se temelj nalazi cca $170 \mathrm{~cm}$ od današnje razine terena.

Uz istočni kameni ogradni zid parcele (SJ 12) pronađen je kameni bunar (SJ 2), koji ima betonsku kapu i dva betonska poklopca. Može se slobodno pretpostaviti da je bunar stariji, te da je kasnije dobio betonsku kapu i betonske poklopce, koji na svome spoju imaju kružni otvor kroz koji je najvjerojatnije prolazila pumpa. Dimenzije betonske kape i poklopaca iznose 160×160 cm. Bunar je djelomično zatrpan do dubine od oko $2,5 \mathrm{~m}$, te u njemu nije bilo vode. Apsolutna visina betonskih poklopaca iznosi $+170,12 \mathrm{~m}$, a betonske kape $+170,02$ (gornja visina) i $+169,72$ (slika 7).

Uz kameni bunar pronađeno je opločenje od opeke (SJ 3), koje je na sjevernoj strani spojeno s njim (slika 7), dok je na istočnoj strani spojeno s kamenim zidom (SJ 12). Opeke su postavljene u dva reda, jedan iznad drugog. Dimenzije opločenja su cca $200 \times 200 \mathrm{~cm}$. Na sjevernoj strani, tik uz bunar ide kanalić, koji je od opločenja niži za visinu jedne opeke. Približno u sredini opločenja, na kamenom zidu (SJ 12), nalaze se okomito postavljene 3 kukice (sve različite), za koje se može pretpostaviti da su povezane sa opločenjem. 


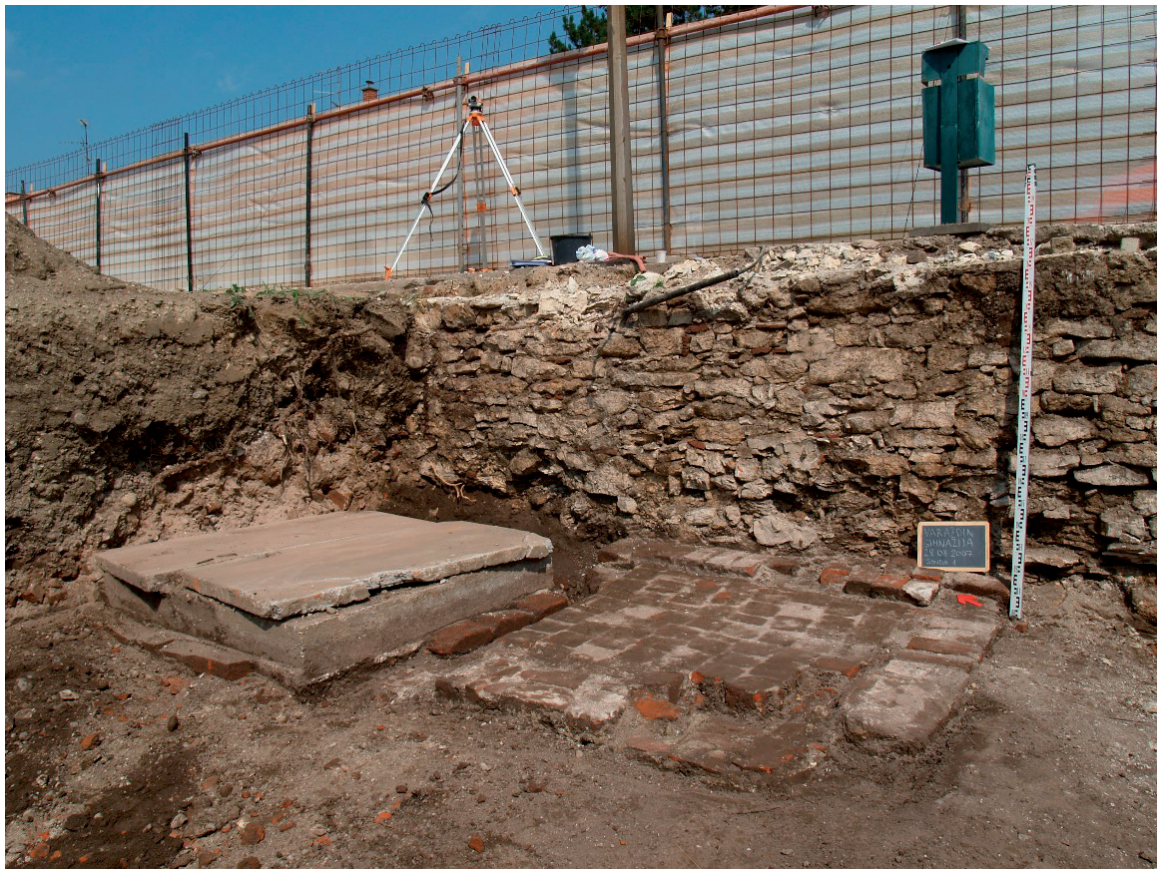

Slika 7. Pogled na bunar (SJ 2) i opločenje od opeke pronađeno uz njega (SJ 3), koji se nalaze neposredno uz istočni ogradni zid parcele kod (SJ 12), foto: M. Korunek-Medved

Neposredno uz opločenje od opeke, na južnoj strani, nalazi se urušenje zida (SJ 4). U sondi 1 dužina mu iznosi $235 \mathrm{~cm}$, a širina $162 \mathrm{~cm}$, dok mu je visina uz kameni zid $135 \mathrm{~cm}$. Urušenje je najvećim dijelom od kamena, dok samo mjestimično nailazimo na opeku. Ovakav sastav zida odgovara kamenom zidu, te se može pretpostaviti da se radi o urušenju tog zida. Naime, zid koji je nedavno srušen bio je izgrađen od opeke, što nas navodi na zaključak da je kameni zid iznad današnje razine terena bio srušen još u vrijeme kad je razina terena bila niža. Donja kota urušenja odgovara visini opločenja od opeke i gornjoj koti SJ 5.

Svi ovi nalazi navode nas na zaključak da je razina terena bila mnogo niža od današnje, koja je u ravnini s ulicom (Preradovićeva ulica). Naime, na ovom prostoru nalazili su se vrtovi koji su pripadali gimnaziji, a 70-tih godina 20. stoljeća oni su zatrpani, te je razina terena nivelirana s uličnom. Razina terena prije zatrpavanja utvrđena je na apsolutnoj visini od $+169,78$ do $+169,74$ m. Ovo nasipavanje terena (SJ 1) sastoji se od novijeg građevinskog materijala, kanalizacijskih cijevi, te betonskih elemenata. U ovoj sondi izdvojene su SJ 1, 2, 3, 4, 5, 6, 7, 9, 10 i 12. Najzanimljivija je SJ 7 u kojoj je pronađena velika količina pokretnih nalaza. 
Ova SJ je zapravo samo grabište, koje na donjem dijelu ima sloj batude u kojem također ima pokretnih nalaza. Posebni nalazi izdvojeni iz ove sonde označeni su brojevima PN 1-27 i PN 30-34.

U produženju ove sonde pronađena je vapnara (gašeno vapno), koja je postavljena unutar SJ 6, SJ 7 i SJ 10. Tlocrtno ima elipsoidni oblik, a dimenzije su joj 1,30x1,60 m (orijentacija S-J). Ovo je potvrdilo navode da su na ovoj parceli bile vapnare koje su korištene kod izgradnje gimnazije.

U ovoj sondi na udaljenosti od 13,30 m od istočnog ogradnog zida parcele (SJ 12) unutar SJ 5 pronađen je pravilan horizontalni sloj od opeka (djelomično sadrži i kamen), koji je označen kao SJ 9. Čitav sloj je jako lomljiv. Dimenzije su mu $5 \times 0,50 \mathrm{~m}$, sa orijentacijom S-J. Debljina sloja je $20 \mathrm{~cm}$.

\section{Sonda 2}

Duljina ove sonde bila je 30 metara, jer se njome trebao dobiti presjek parcele na kojoj je bila planirana nova građevina. Na ostalom dijelu parcele nije se išlo do ove duljine (gledano od istočnog ogradnog zida prema zapadu), jer planirana manja građevina nema podrum na tom dijelu. Ukupno su dimenzije sonde $3 \times 30$ metara.

Neposredno uz istočni ogradni zid parcele pronađen je zid od opeke, koji je označen kao SJ 8 (slika 8). Ovaj zid zidan je od 6 redova opeke, od kojih su dva donja reda ispod hodne površine (SJ 5).

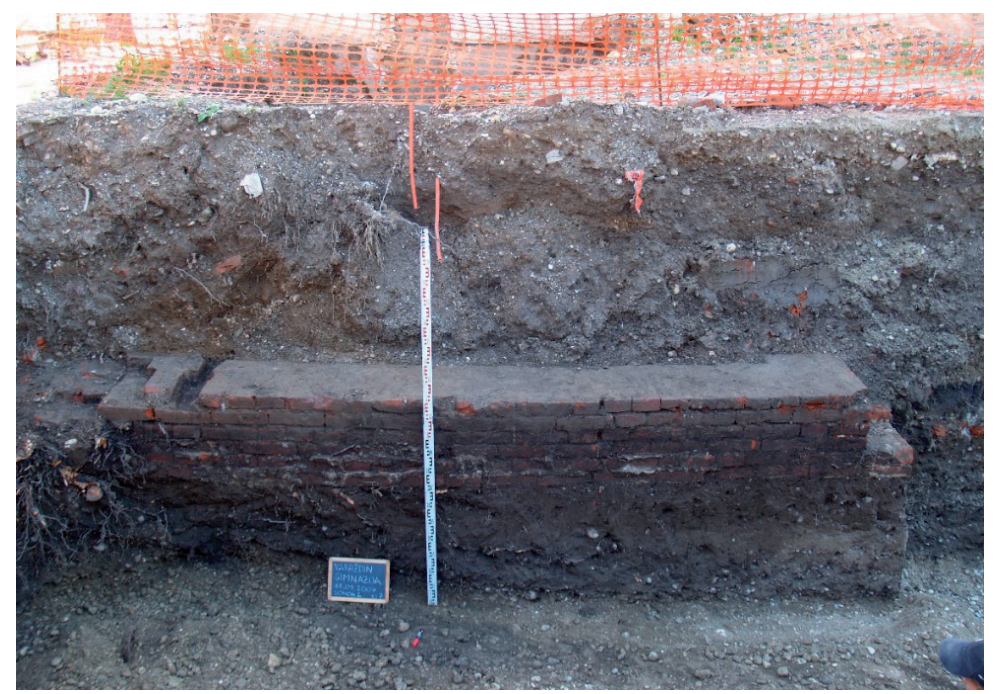

Slika 8. Zid od opeke (SJ 8), foto: M. Korunek-Medved 
U sondi 2 uočeno je da se zid pod pravim kutem (sa zapadne strane) nastavlja prema jugu. Na istočnoj strani zid je oštećen, a oštećenje je izazvao veliki korijen, koji je ovdje pronađen. Tijekom arheološkog nadzora, na dijelu između ovog zida i zida današnje gimnazije, otvoren je čitav zid (SJ 8). On tlocrtno čini pravokutnik, a proteže se prema jugu uz ogradni istočni zid, pod pravim kutem prati južni ogradni zid parcele, te se ponovo pod pravim kutem spaja sa zidom u sondi 2. Namjena ovog zida nije u potpunosti definirana, ali obzirom da se radi o zidu koji je visinski građen od 6 redova opeke, a njegova debljina sugerira da on nije ostatak temelja neke građevine, možemo pretpostaviti da se radi o strukturi vezanoj uz funkcioniranje vrtova i voćnjaka. Obzirom na kvalitetu i dimenzije opeka, ovdje se radi o recentnijoj strukturi. Visinski odgovara razini funkcioniranja na kojoj je pronađen bunar i opločenje od opeke.

U ovoj sondi također je utvrđena SJ 9 unutar SJ 5, koja od zida od opeke (SJ 8) ide prema zapadu. Duljina sloja je 2,10 m, a širina 0,50 m (orijentacija I-Z). Ovdje je sloj također pravilan, a visinom odgovara visini temelja zida od opeke.

Uz SJ 8 u SJ 7 pronađeno je veći broj ulomaka posuda za zagrijavanje hrane (tronožaca). Dvije su izdvojene kao PN 28 i PN 29. Zanimljivo je da sonda 2 ima znatno manje pokretnih nalaza od sonde 1 . Posebni nalazi izdvojeni iz ove sonde označeni su brojevima PN 28-29.

\section{Sonda 3}

Ova sonda nalazi se sjeverno od sonde 1, a ukupne dimenzije su joj 5x19 metara. Ovom sondom zaokružen je sjeverni dio planirane građevine.

Stratigrafske jedinice koje nalazimo u ovoj sondi su SJ 1, SJ 5, SJ 6, SJ 7 i SJ 10. Na dijelu od istočnog ogradnog zida parcele prema zapadu, SJ 5 je ispunjena građevinskom šutom, pretežno opekama, do duljine od 2,5 metara. Na dijelu neposredno uz bunar (SJ 2) nema nalaza, jer ovdje imamo SJ 5 umjesto SJ 6 i SJ 7, a ta situacija odgovara stanju u sondi 1. Ovo potvrđuje konstataciju da su izgradnjom bunara uništene SJ 6 i SJ 7. Ovo se moralo dogoditi nešto prije ili istovremeno sa ponovnim zatrpavanjem terena kada nastaje SJ 5.

Samo grabište (SJ7) u ovoj sondi bogato je nalazima. Od pokretnih nalaza najviše je pronađeno ulomaka neocakljene keramike (posude za svakodnevnu uporabu), dosta fragmenata zeleno ocakljene keramike, te nešto ulomaka slikane keramike. Pronađeno je i dosta fragmenata stakla, prvenstveno od staklenih bočica sa tankim stjenkama. Svi nalazi pećnjaka jako su fragmentirani, a stilski odgovaraju već pronađenima u sondi 1 . Od metalnih nalaza treba spomenuti jednu u potpunosti očuvanu potkovu. Posebni nalazi izdvojeni iz ove sonde označeni su brojevima PN 35-50. 


\section{Sonda 4}

Ova sonda bila je smještena uz zapadni rub planirane građevine, a spaja sondu 1 i sondu 2. Jedina je orijentirana u smjeru sjever-jug, a dimenzije su joj $6 \times 18$ metara. Sa njezinim istraživanjem krenulo se sa sjevera.

Ovdje imamo istu stratifikaciju kao u prijašnjim sondama, ali je u ovoj sondi SJ 7 tanja, te je u njoj pronađeno nešto manje pokretnih arheoloških nalaza. Najviše ima ulomaka neocakljene keramike (posude za svakodnevnu uporabu), dosta ulomaka zeleno ocakljene keramike, te nekoliko primjeraka sa slikanim motivima. Pronađeno je i nekoliko fragmenata stakla, te metalnih nalaza. Posebni nalazi izdvojeni iz ove sonde označeni su brojevima PN 51-56.

\section{Sonda 5}

Dimenzije ove sonde su 9x13 metara, a bila je smještena sjeverno od sonde 2. Na oko 2,50 metra zapadno od istočnog ogradnog zida parcele, u sredini sonde pronađen je veći broj ulomaka pećnjaka u SJ 7. Pećnjaci su jako fragmentirani i ima ih od više različitih peći, koje ne pripadaju istim vremenskim i stilskim razdobljima. Pa tako imamo zeleno ocakljenih, neocakljenih i višebojnih. Između njih pronađeno je i nekoliko ulomaka keramike i stakla. Od pokretnih nalaza u čitavoj sondi pronađeno je najviše fragmenata neocakljene keramike (posude za svakodnevnu uporabu), dosta ulomaka zeleno ocakljene keramike, te nešto fragmenata slikane keramike. Pronađeno je i dosta ulomaka stakla, te nešto metalnih predmeta. Posebni nalazi izdvojeni iz ove sonde označeni su brojevima PN 57-72.

\section{Sonda 6}

Ova sonda smještena je između sonde 1 na sjeveru i sonde 5 na jugu. Dimenzije su joj 9x13 metara.

Kao i u sondi 1 pronađeno je urušenje zida (SJ 4). U sondi 6 dužina mu iznosi $2,30 \mathrm{~m}$, a širina $1,25 \mathrm{~m}$, dok mu je najviša visina uz kameni zid cca $130 \mathrm{~cm}$. Urušenje je najvećim dijelom od kamena, dok samo mjestimično nailazimo na opeku, kao i u sondi 1.

Najviše je pronađeno fragmenata neocakljene keramike (posude za svakodnevnu uporabu), zatim zeleno ocakljene keramike, te nešto malo slikanih ulomaka. Imamo i nalaze ulomaka pećnjaka, stakla i metala. Posebni nalazi izdvojeni iz ove sonde označeni su brojevima PN 73-80. 


\section{POKRETNI ARHEOLOŠKI NALAZI}

Na čitavom istraženom terenu pronađeni su brojni pokretni arheološki nalazi. Svi koji su pronađeni u SJ 1 su recentni i nisu nam zanimljivi, dok je u SJ 5 pronađeno samo nekoliko nalaza. U SJ 6 imamo dosta ulomaka keramičkih posuda, a najviše pokretnih nalaza bilo je u SJ 7. Ovaj najniži sloj, koji se nalazi neposredno iznad zdravice, arheološki je najzanimljiviji, jer predstavlja samo grabište, te su u isušenom sivom mulju pronađeni brojni ulomci keramike, pećnjaka, stakla i metalnih predmeta.

Ovi novovjekovni nalazi bitni su nam za bolje razumijevanje razvoja grada Varaždina i učestalosti stilskih utjecaja koji su u određenim razdobljima bili dominantni.

\section{Pećnjaci}

Pećnjak je u početku bio strogo funkcionalni dio kaljeve peći, kojem je svrha bila što duže zadržavanje topline. S vremenom, kako ukus naručitelja biva sve istančaniji, pećnjaci se počinju ukrašavati. U početku su na njima bile jednostavne dekoracije, koje s vremenom postaju sve kompleksnije, a kroz čitavo vrijeme svoje produkcije prate ukus vremena. Kaljeve peći s ovakvim pećnjacima postaju sastavni dio dekoracije pojedinih prostorija i odraz platežne moći naručitelja, te gube strogo funkcionalnu namjenu. Razlikujemo nekoliko tipova pećnjaka. Najstariji tipovi nalikuju keramičkim zdjelastim posudama, koje mogu imati četvrtasti ili trokutasti gornji dio, dok je dno u pravilu okruglog oblika. Kroz 14. stoljeće od ovakvih, najstarijih tipova pećnjaka, razvijaju se pećnjaci s prednjom dekorativnom pločom, koja na sebi nosi ukras s reljefnim figuralnim, geometrijskim ili florealnim prikazom. ${ }^{13}$

Tijekom ovih istraživanja pronađeni su brojni ulomci pećnjaka, ali oni nisu bili deponirani u cjelinama, nego su fragmenti stilski istog pećnjaka nađeni i u nekoliko sondi. Takva situacija može se objasniti jedino činjenicom, da su oni deponirani kada je grabište još bilo ispunjeno vodom.

Pronađena su samo dva pećnjaka sa figuralnim prikazima. Prvi prikazuje kerubina (slika 9), a možemo ga datirati na sam kraj 17. stoljeća, dok drugi na sebi nosi prikaz Boga Oca (slika 10). Kako centralni prikaz nije sačuvan, jedino što se može iščitati je da se radi o prikazu Boga Oca u slavi, što dodatno potkrepljuje prikaz svirača s lijeve strane. Bog Otac prikazan je kao starac sa bradom i aureolom oko glave okružen oblacima.

13 O razvoju pećnjaka detaljnije u: Ivana ŠKILJAN, Srednjovjekovni i ranonovovjekovni pećnjaci Slavonije, doktorska disertacija, Zagreb 2015. 


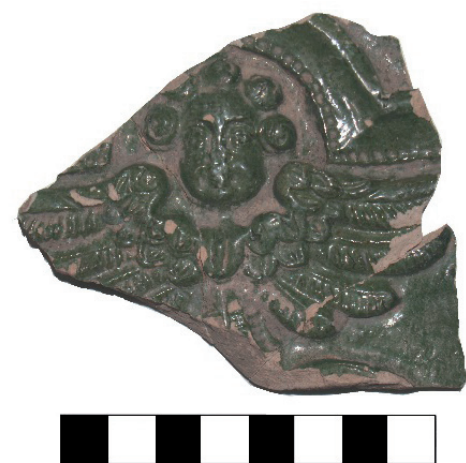

Slika 9. Pećnjak s prikazom kerubina (PN 59), ulomak, foto: M. Korunek-Medved

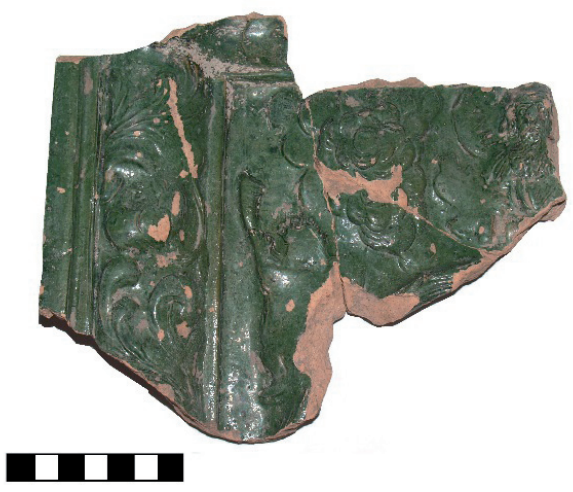

Slika 10. Pećnjak s prikazom scene Boga Oca (PN 1), ulomak, foto: M. Korunek-Medved

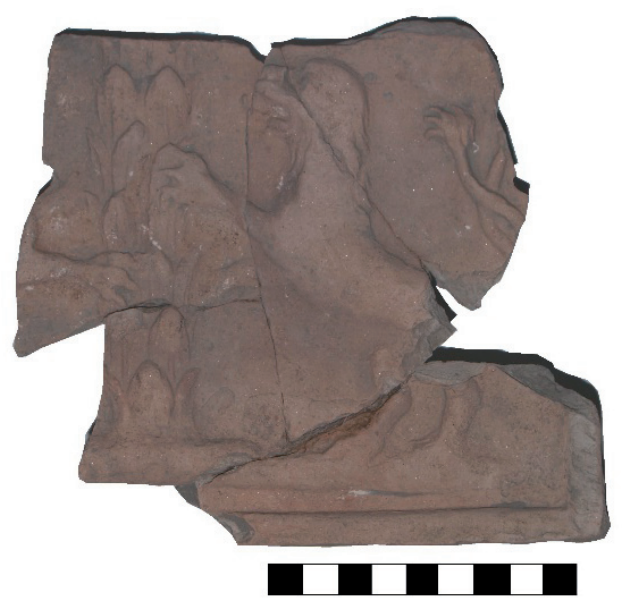

Slika 11. Pećnjak s pavlinskim grbom (PN 64), ulomak, foto: M. Korunek-Medved

Od životinjskih motiva najzanimljiviji je neocakljeni prikaz dva nasuprotno postavljena lava koji čuvaju palmu (slika 11). Ovakvi prikazi karakteristični su za 16. i 17. stoljeće, a gotovo u pravilu se povezuju s grbom crkvenog reda Pavlina. Ovaj pećnjak također je fragmentno očuvan, ali se jasno može iščitati prikaz na prednjoj ploči. Fragment pećnjaka na kojem je prikazana ptica na vrhu palme pripada istoj sceni, ali ne može se sa sigurnošću potvrditi da se radi o istom peć- 
njaku, obzirom da nedostaje dosta dijelova, a ovakve peći bile su sastavljene od više istovjetnih pećnjaka.

Imamo i nekoliko ulomaka koji na sebi imaju prikaze orla. Na njima sama scena nije u potpunosti čitljiva, ali se na očuvanim fragmentima jasno vidi perje i glava orla, a svi su zeleno ocakljeni.

Najbrojniji su ulomci pećnjaka s florealnim i geometrijskim prikazima. Najviše imamo onih koji prikazuju rozete postavljene unutar mreže (rombovi). Pronađeno je nekoliko vrsta ovog prikaza, a razlikuju se po kvaliteti obrade i obliku rozeta. Imamo ih neocakljenih i zeleno ocakljenih. Ovakvi pećnjaci pronađeni su do sada na više lokacija u samom gradu, a njihova učestalost i brojnost navodi na zaključak o postojanju radionice, ili barem jednog jačeg stilskog utjecaja. $\mathrm{Na}$ neocakljenim i zeleno ocakljenim pećnjacima s florealnim prikazima nailazimo i na raznovrsne motive vitica i prepleta.

Zanimljiv je i fragment s prikazom arkada, ispod kojih se nalaze krugovi, unutar kojih su križevi. Krugovi s križevima nalaze se i na spojevima arkada. Ovaj fragment je zeleno ocakljen, a ima zubčasti završetak. Ovo je jedan od rijetkih primjeraka pećnjaka koji nije pećnjak s punom prednjom stranom na kojoj se nalazi dekoracija, nego se nalazio na rubu kaljeve peći.

\section{Keramika}

Fragmenti keramičkih posuda svakako su najbrojniji pokretni nalazi pronađeni tijekom ovih istraživanja. Najviše ima ulomaka keramičkih posuda koje su služile za svakodnevnu uporabu, te nisu ni ukrašene ni ocakljene. Pronađeni su i brojni fragmenti poklopaca raznih dimenzija i oblika, koji su svi u pravilu koničnog oblika s kružnom ručkom i nisu ocakljeni.

Od ocakljenih posuda najviše ima fragmenata zelene boje, a nešto je manje onih sa smeđom ocaklinom. Najzanimljivije su posude sa tri noge (tronošci) koje su služile za zagrijavanje hrane.

Posuda za zagrijavanje hrane pronađena je u sondi 2 u neposrednoj blizini zida od opeke. Na donjoj strani dna ima debeli sloj gara, što upućuje na to da je bila dugo u uporabi (slika 12). Uz nju su pronađeni ulomci još pet posuda ovog tipa, od kojih su tri zeleno ocakljene. Ovakve posude upotrebljavaju se tijekom više stoljeća.

Od zeleno ocakljenih posuda imamo zdjele, posude za zagrijavanje hrane i tanjure. Na njima pronalazimo nekoliko vrsta ocakline koja je različite kvalitete. Ove posude su različitih dimenzija i oblika. 


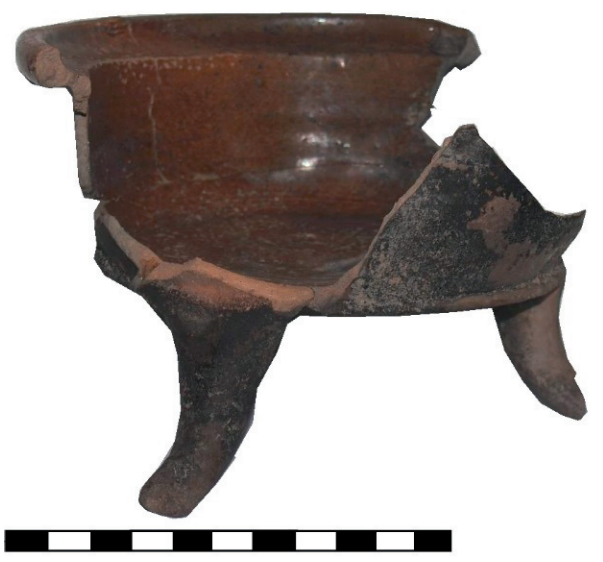

Slika 12. Posuda za zagrijavanje hrane - tronožac

(PN 57), (PN 28), foto: M. Korunek-Medved

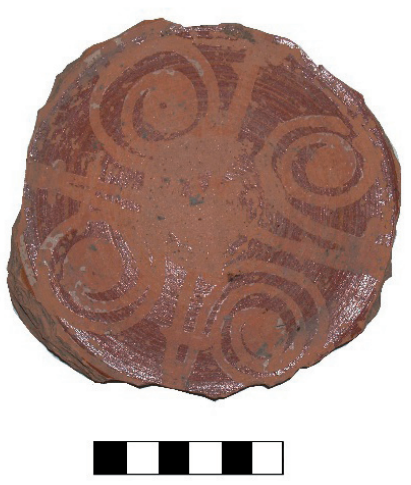

Slika 13. Tanjur, crvena ocaklina foto: M. Korunek-Medved

Zanimljivi su i nalazi keramike sa slikanim ukrasom. Ukras je pretežno geometrijski, ali nalazimo i florealnu dekoraciju u vidu vitica. Najviše ima fragmenata na kojima prevladava crvena boja, dok je ukras bio bijeli, ali je propao pa ga nalazimo samo djelomično. Ovakav ukras nalazimo samo na tanjurima. Zanimljivo je u cijelosti sačuvano dno dubokog tanjura oslikano tamnocrvenom bojom sa bijelim vitičastim ukrasom od paste, koja je s vremenom otpala, a okvirno se može datirati u 16-17. stoljeće (slika 13).

\section{Lule za pušenje}

Tijekom ovih istraživanja pronađene su dvije fragmentarno sačuvane lule za pušenje. Obje su keramičke, jednostavnog oblika i bez dekoracije. Jedna od njih označena je kao PN 13 i ima na sebi smeđu ocaklinu (slika 14), dok je druga neocakljena.

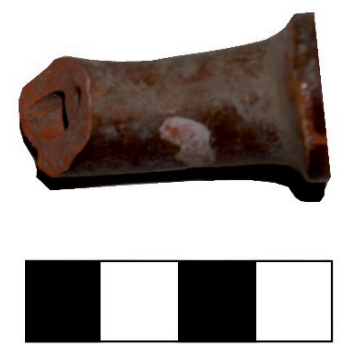

Slika 14. Lula za pušenje, smeđe ocakljena (PN 13),

foto: M. Korunek-Medved 


\section{Metalni predmeti}

Metalnih nalaza pronađeno je relativno malo, što iznenađuje s obzirom da se ovdje radilo o obrambenom grabištu uz gradski bedem. Pronađene su dvije cijele potkove, te jedna fragmentarno očuvana. Od ostalih metalnih nalaza pronađeni su samo željezni čavli (slika 15).

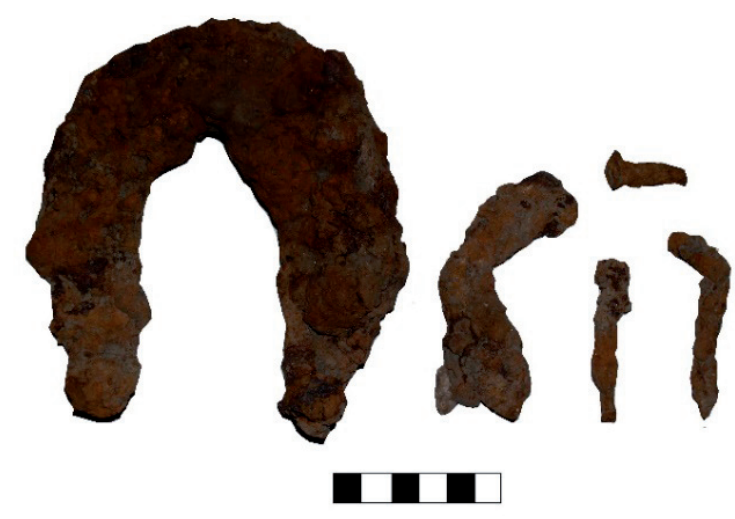

Slika 15. Metalni nalazi (potkova PN 30, ulomak potkove PN 25 i čavli PN 26), foto: M. Korunek-Medved

\section{Staklo}

Tijekom ovih istraživanja pronađen je velik broj ulomaka stakla. Prevladavaju fragmenti staklenih bočica manjih dimenzija sa tankim stjenkama. Najzanimljiviji su svakako nalazi kuttrolfa. Pronađeni su fragmenti ukupno devet kuttrolfa, koji se razlikuju po dimenzijama, ali i po boji stakla, pa tako imamo one od bezbojnog i one od zelenog stakla (slika 16). Ovakav tip staklene boce nije bio za svakodnevnu uporabu, nego ga možemo staviti u rang luksuzne robe. Ovi pronađeni fragmenti pripadaju različitim povijesnim razdobljima, te su kao takvi dokaz o dugoj tradiciji uporabe ovakvih boca na području grada Varaždina. 

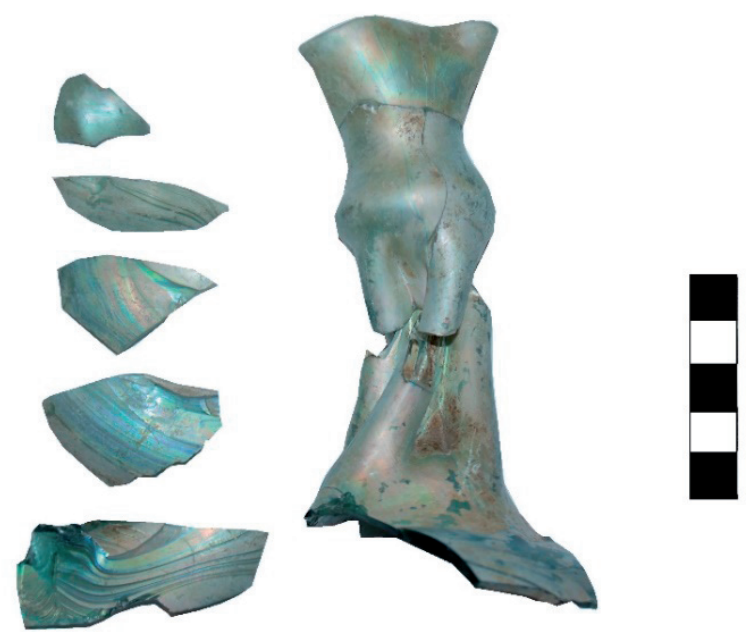

Slika 16. Ulomci kuttrolfa (PN 2), foto: M. Korunek-Medved

Svi pronađeni ulomci stakla pripadaju staklenim bočicama, od kojih je najveći dio imao izrazito tanke stjenke. U ovakvom tipu bočica čuvalo se nešto što je bilo izrazito vrijedno, rijetko i skupo u to vrijeme, te kao takvo nije bilo dostupno svakome. Očuvano je dosta gornjih dijelova bočica, a posebno je zanimljiv primjerak koji ima nepravilan i prema van izvučen obod, a očuvano rame bočice ukazuje da je donji dio bio izrazito trbušat.

Uz ovakve bočice pronađeno je i nekoliko fragmentno očuvanih staklenih boca debljih stijenki, koje u pravilu imaju četvrtasto dno. Uz ovakve nalaze jedina iznimka su dva fragmenta prozorskog stakla.

\section{ZAKLJUČNE NAPOMENE}

Zaštitna arheološka istraživanja i arheološki nadzor provedeni su na dijelu zatrpanog istočnog gradskog grabišta uz nekadašnju ulicu Via Fossata ambiens, koja je okruživala utvrđeni grad.

Predmetna istraživanja provelo je Ministarstvo kulture, Uprava za zaštitu kulturne baštine, Konzervatorski odjel u Varaždinu, a sredstva, fizičke radnike, stroj za iskop i geodetska snimanja osigurao je investitor, tvrtka T.P.N. Varaždin.

U prvoj fazi istraživanja, sa dvije sonde, utvrđen je karakter lokaliteta, te je temeljem rezultata tih istraživanja određeno daljnje postupanje. Ukupno je 
otvoreno 6 sondi u kojima je izdvojeno 13 stratigrafskih jedinica, od kojih je najzanimljivija SJ 7 koja predstavlja samo grabište, a nalazi se neposredno iznad zdravice. U njoj se, u isušenom mulju sive boje, nailazilo na brojne ulomke keramike, pećnjaka, stakla i metalnih predmeta. Kao što je ranije objašnjeno, grabište je zatrpano tijekom 19. stoljeća. U toj ispuni razlikujemo dvije razine (SJ 6 i 5), od kojih SJ 5 predstavlja humusni sloj koji povezujemo s vrtovima, a SJ 6 ispunu s nalazima. Gornja kota SJ 5 predstavlja razinu funkcioniranja terena tijekom 19. i 20. stoljeća. Na ovoj visini, neposredno uz kameni zid (SJ 12), koji omeđuje parcelu na istočnoj strani, pronađen je kameni bunar (SJ 2) s betonskom kapom i dva poklopca, opločenje od opeke (SJ 3) u sondi 1, te u sondi 2 zid od opeke (SJ 8). Ta razina terena može se pratiti na čitavom istraženom dijelu, sa relativno malim pomacima u visini. U ovom sloju nalazimo fragmente keramike, te nešto malo pećnjaka, stakla i metalnih premeta, ali ukupna količina je znatno manja nego u SJ 7. Najgornji sloj (SJ 1) je recentna ispuna, odnosno nasip, izveden se svrhom niveliranja terena. Ovaj sloj nije bio arheološki zanimljiv.

U svim sondama utvrđen je isti raspored SJ 1, 5, 6, 7 i 10 (sa neznatnim pomacima u visini). Kao što je bilo i za očekivati u samom grabištu (SJ 7) pronađeno je najviše pokretnih arheoloških nalaza. Fragmenti keramičkih posuda su najbrojniji, a najviše ima ulomaka keramičkih posuda koje su služile za svakodnevnu uporabu, te nisu ni ukrašene ni ocakljene. Od ocakljenih posuda najviše ima fragmenata zelene boje, a nešto je manje onih sa smeđom ocaklinom. Zanimljivi su i nalazi keramike sa slikanim ukrasom.

Tijekom istraživanja pronađeno je mnogo fragmenata pećnjaka. Svi su jako fragmentirani. Posebno treba spomenuti pećnjak s prikazom kerubina i pećnjak s prikazom Boga Oca. Od pećnjaka sa životinjskim prikazima najzanimljiviji je onaj koji na sebi ima dva nasuprotno postavljena lava koji čuvaju palmu. Najbrojniji su fragmenti pećnjaka s florealnim i geometrijskim prikazima, a među njima se učestalošću ističu oni s prikazima rozeta postavljenih unutar mreže.

Tijekom ovih istraživanja pronađen je velik broj fragmenata stakla. Prevladavaju fragmenti staklenih bočica manjih dimenzija sa tankim stjenkama. Najzanimljiviji su svakako nalazi kuttrolfa, a pronađeni su fragmenti ukupno njih devet.

Provedena arheološka istraživanja potvrdila su povijesne podatke da na predmetnoj parceli nikada nije bilo čvršće arhitektonske izgradnje. Početni nivo terena odgovara nivou ulice, ali ovim istraživanjima utvrđeno je da je nivo parcele bio znatno niži (oko $170 \mathrm{~cm}$ ). Naime, na ovom prostoru nalazili su se vrtovi koji su pripadali gimnaziji, a 70-tih godina 20. stoljeća oni su zatrpani, te je razina terena nivelirana s uličnom. 
Prvobitni cilj istraživanja bila je determinacija samog grabišta, kao dijela obrambenog sustava gradskih bedema. Međutim, pronađeni su brojni pokretni nalazi, koji ocrtavaju sliku grada Varaždina tijekom više stoljeća i stilske utjecaje koji su se tijekom vremena mijenjali. Pokretne arheološke nalaze okvirno možemo datirati od 15. do 19. stoljeća. Najviše je nalaza ulomaka keramičkih posuda, zatim pećnjaka, stakla, te nešto metalnih predmeta.

\section{LITERATURA}

1/ IVy LENTIĆ KUGLI, Varaždin nakon požara 1776, Zagreb 1973.

2/ Marija MIRKOVIĆ, „O spajanju unutarnje varoši i gradskih predgrađa," Godišnjak GMV, 1962./63., 42-66.

3/ Mira ILIJANIĆ: „Varaždinske gradske zidine, Prilog historijatu našeg grada,“ Zbornik radova Urbanizam, graditeljstvo, kultura, Varaždin 1999., 157.-159.

4/ IVy LENTIĆ KUGLI, Zgrade varaždinske povijesne jezgre, Zagreb 2001.

5/ Marijana KORUNEK, „Varaždin - Preradovićeva 14, arheološka iskopavanja,“ Hrvatski arheološki godišnjak 4/ 2007, Zagreb 2008., 167 - 169.

6/ Marijana KORUNEK, Varaždin, Preradovićeva 14 - Rezultati zaštitnih arheoloških istraživanja i arheološkog nadzora, izvješće, prosinac 2007. (dokumentacija KOVŽ)

7/ Mirela SLUKAN ALTIĆ, Povijesni atlas gradova - Varaždin, V. svezak, Zagreb 2009.

8/ Ivana ŠKILJAN, Srednjovjekovni i ranonovovjekovni pećnjaci Slavonije, doktorska disertacija, Zagreb 2015. 


\section{SAŽETAK \\ ZAŠTITNA ARHEOLOŠKA ISTRAŽIVANJA PROVEDENA NA LOKACIJI PRERADOVIĆEVA 14 U VARAŽDINU - PRILOG POZNAVANJU GRADSKIH GRABIŠTA}

Zaštitna arheološka istraživanja provedena su tijekom 2007. godine na lokaciji Preradovićeva 14 u Varaždinu za potrebe dogradnje I. gimnazije. Obuhvatila su dio zatrpanog istočnog grabišta, koje je bilo dio obrambenog sustava grada Varaždina od sredine 15. do početka 19. stoljeća. Provedena arheološka istraživanja uglavnom su nam potvrdila dostupne povijesne podatke o gradskom grabištu i njegovom zatrpavanju početkom 19. stoljeća, kao i rezultate ranije provedenih istraživanja na sličnim lokacijama u gradu Varaždinu. Zanimljivost je podatak da je razina funkcioniranja terena do 70-tih godina 20. stoljeća bila niža za oko $170 \mathrm{~cm}$ od današnje, te da je relativno kasno nivelirana s ulicom i okolnim parcelama. Razlog možemo pronaći u činjenici da je ova parcela bila ograđena kamenim zidom i korištena kao vrt gimnazije, te evidentno ranije nije bilo potrebe za ovakvim zahvatom. Najzanimljivije je samo grabište u kojem je pronađena velika količina pokretnih arheoloških nalaza. Fragmenti keramičkih posuda su najbrojniji pokretni nalazi pronađeni tijekom ovih istraživanja, a najviše ima onih koji pripadaju keramičkim posudama koje su služile za svakodnevnu uporabu, ali imamo i ocakljenih i bojanih fragmenata. Pronađeno je mnogo pećnjaka, ali svi su jako fragmentirani, a posebno treba spomenuti pećnjake s figuralnim i životinjskim prikazima. Pronađeno je i dosta ulomaka staklenih bočica, a najzanimljiviji su fragmenti devet boca tipa kuttrolf. Metalnih nalaza imamo relativno malo, što iznenađuje s obzirom da se ovdje radilo o obrambenom grabištu uz gradski bedem. Sve pokretne arheološke nalaze možemo datirati u period od 15. do 19. stoljeća, što je ujedno i vrijeme funkcioniranja grabišta kao dijela obrambenog sustava grada Varaždina.

Ključne riječi: Varaždin; gradski obrambeni sustav; istočno gradsko grabište; urbana arheologija; pokretni arheološki nalazi. 


\section{SUMMARY}

PROTECTIVE ARCHAEOLOGICAL RESEARCH CONDUCTED AT THE LOCATION PRERADOVIĆEVA 14 IN VARAŽDIN - CONTRIBUTION TO THE KNOWLEDGE OF CITY DITCHES

Protective archaeological research was carried out in 2007. at the location Preradovićeva 14 in Varaždin, where the extension of the the First Gymnasium high school was planed. They covered the part of the buried eastern ditch that was part of the defense system of Varaždin City from the mid. 15th to the early 19th century. Archaeological research has largely confirmed the available historical data on the town's ditches system, and its backfilling at the beginning of the 19th century, as well as the results of earlier research on similar locations in the City of Varaždin. Interestingly, the level of ground in this location was about 170 $\mathrm{cm}$ lower than today's up to the 1970s, and was relatively late aligned with the streets and surrounding plots. The reason we can find in the fact that this plot was enclosed by a stone wall and used as a gymnasium garden, and obviously earlier there was no need for aligning it. The most interesting archaeological layer was the eastern ditch itself, where a large amount of archaeological finds were found. The fragments of ceramic vessels are certainly the most numerous finds found during these researches, and most of them belong to ceramic vesseIs used for everyday use, but we also have waxed and painted fragments also. Many parts of stoves have been found, but they were all very fragmented. A large number of glass vials have been found, and the most interesting are the fragments of nine bottles of kuttrolf. We have relatively little metal findings, which is surprising given that this was a defensive city ditch. All archeological finds can be dated to the period from the 15th to 19th century, which is also the time that the defense system was in use.

Key Words: Varaždin; city defense system; eastern town ditch; urban archeology; archaeological finds. 
